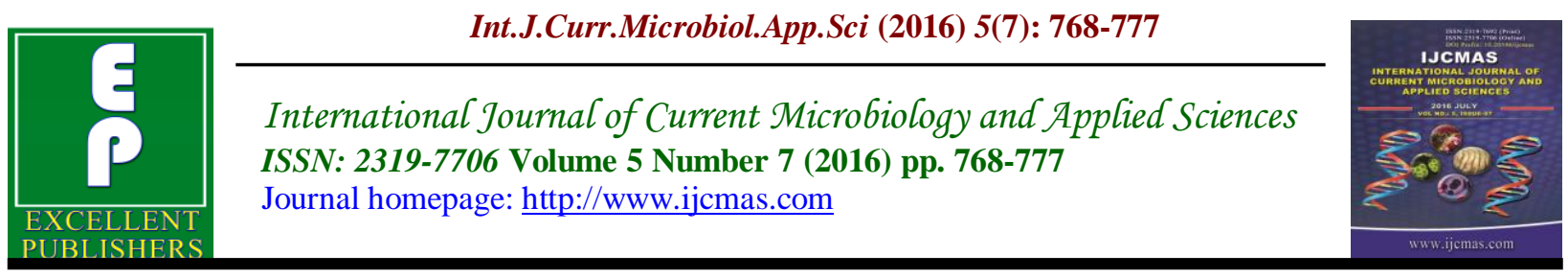

Original Research Article

http://dx.doi.org/10.20546/ijcmas.2016.507.088

\title{
Prevalence of Thalassaemia Mutations in Sickle Cell Disease Population of Madhya Pradesh, Central India
}

\author{
M.P.S.S. Singh ${ }^{1,2}$, G. Sudhakar ${ }^{2}$ and S. Rajasubramaniam ${ }^{1} *$ \\ ${ }^{1}$ National Institute for Research in tribal health (Indian Council of Medical research), \\ Nagpur Road, Garha Post, Jabalpur-482003, Madhya Pradesh, India \\ ${ }^{2}$ Department of Human Genetics, Andhra University, Visakhapatnam-530003, \\ Andhra Pradesh, India \\ *Corresponding author
}

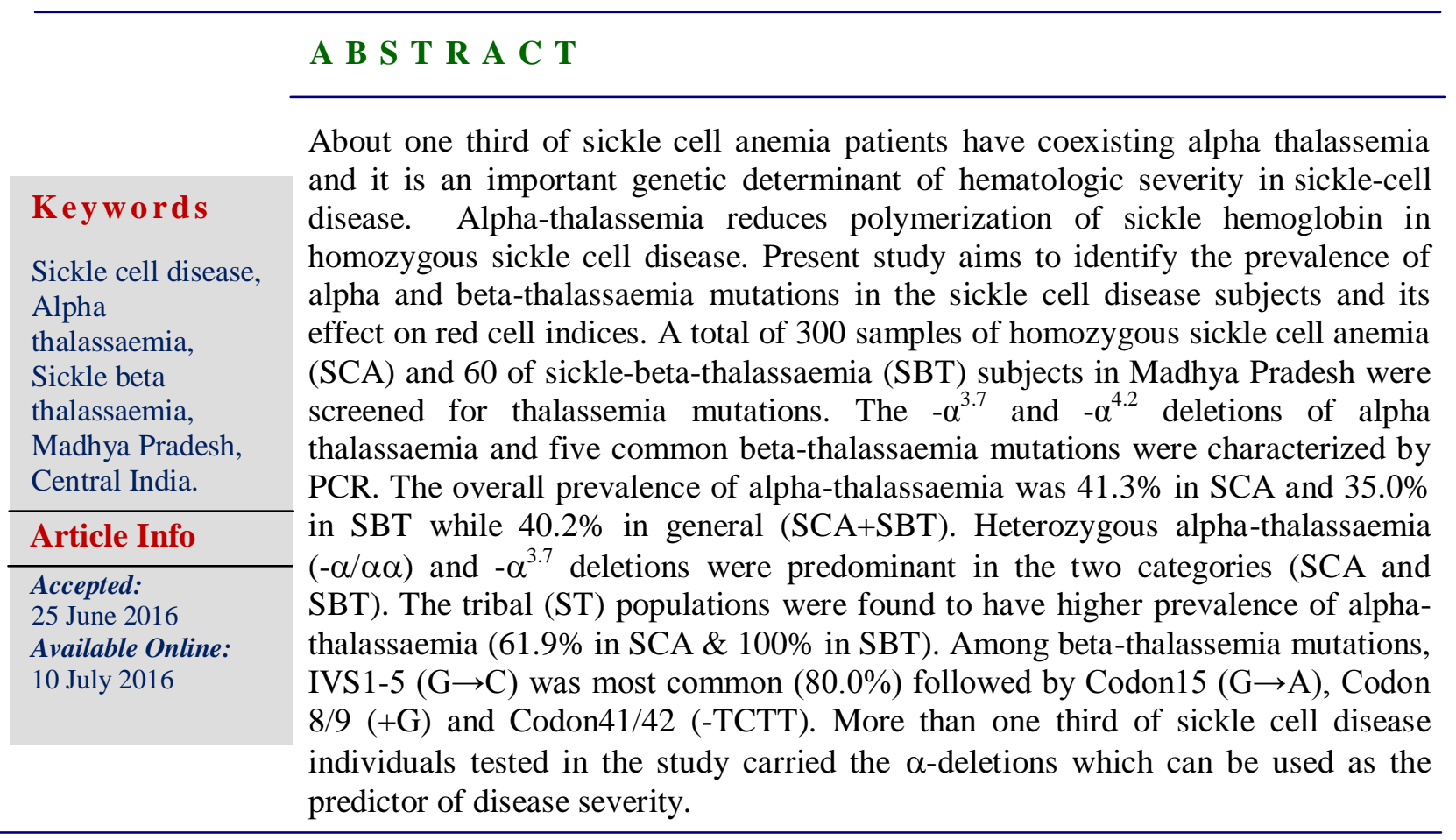

\section{Introduction}

Sickle hemoglobin (HbS) is caused by a single nucleotide substitution $(\mathrm{A} \rightarrow \mathrm{T})$ in the $6^{\text {th }}$ codon of $\beta$-globin gene on chromosome 11 which results in replacement of Glutamic acid (GAG) by Valine (GTG) (Pauling et al., 1949; Ingram 1956). Under deoxygenated conditions, this substitution causes HbS polymerization (Bunn, 1997) and modifies the stability of the hemoglobin leading to the clinical disorder. The homozygous state of the sickle gene $\left(\beta^{\mathrm{S}}\right)$ results in sickle cell anemia (SCA) and is responsible for the most common severe variant of Sickle cell disease. Thalassemias occur due to reduced or no hemoglobin production from lack of synthesis of alpha or beta chains. Alpha thalassemia ( $\alpha$ - 
thalassaemia) is classified into the $\alpha^{0}$ thalassemia when no $\alpha$-chain is produced and $\alpha^{+}$-thalassemia when synthesis of $\alpha$ chain is reduced (Weatherall et al., 2001a). The $\alpha^{+}$-thalassemia is commonly caused by the deletion of one of the linked pair of $\alpha$ globin genes. The common deletions which cause $\alpha^{+}$-thalassaemia are $-\alpha^{3.7}$ deletion (rightward deletion) and $-\alpha^{4.2}$ deletion (leftward deletion) that remove one or more of the duplicated structural $\alpha$-genes (Embury et al., 1980; Higgs, 2013). The frequency of $\alpha^{+}$-thalassaemia varies from $10-20 \%$ in sub-Saharan Africa, over $40 \%$ in Middle Eastern countries and up to $80 \%$ in India and northern Papua New Guinea (Weatherall et al., 2001b; Singh et al., 2016) and these frequencies show a strong correlation with malarial endemicity (Flint et al., 1986).

Beta thalassaemia ( $\beta$-thalassaemia) is also classified into the $\beta^{+}$-thalassaemia wherein synthesis of $\beta$-chains are reduced and $\beta^{0}$ thalassaemia when no synthesis of $\beta$-chains occurs (Weatherall, 2001). The prevalence of $\beta$-thalassaemia varies from $1 \%$ to $20 \%$ in Mediterranean basin and some parts of Africa, the Middle East, South-East Asia, India, Melanesia and the Pacific Islands (Weatherall et al., 2001b). More than 200 mutations are known to be responsible for $\beta$ thalassaemia (Higgs et al., 2012). Among them IVS1-5 $(\mathrm{G} \rightarrow \mathrm{C})$, IVS1-1 $(\mathrm{G} \rightarrow \mathrm{T}), 619-\mathrm{bp}$ deletion, Codon 41/42(-TCTT) and Codon $8 / 9(+\mathrm{G})$ mutations are responsible for more than $80 \%$ of $\beta$-thalassaemia cases in India (Sinha et al., 2009). The present study was carried out to identify the prevalence of $\alpha^{+}$thalassemia mutations $\left(-\alpha^{3.7} \&-\alpha^{4.2}\right)$ and common $\beta$-thalassaemia mutations in the sickle cell disease subjects and their effect on red cell indices. Currently no reports exist indicating the prevalence of alpha and beta thalassaemia mutations in sickle cell disease in Central India.

\section{Materials and Methods}

\section{Sample Collection}

A total of 360 blood samples of sickle cell disease (SCD) individuals were screened for thalassemia mutations after obtaining written and understood consent. All these subjects were registered with NIRTH SCD Clinic. Homozygous Sickle cell anemia (300) and Sicke $\beta$-thalassemia (60) individuals were included in this study. All these subjects were referred from various OPD's of NSCB Medical College, Jabalpur to National Institute for Research in tribal health for the diagnosis of hemoglobinopathies in and around Jabalpur district.

\section{Diagnosis Criteria}

Diagnosis was established and confirmed by Parental investigation. If both parents were found to be heterozygous for sickle hemoglobin, their child was considered as homozygous sickle cell disease (sickle cell anemia-SCA). If one parent was heterozygous for sickle hemoglobin and other parent has normal hemoglobin pattern with elevated $\mathrm{HbA}_{2}$ levels, their child was considered as double heterozygous for sickle gene and thalassaemia gene (sickle beta thalassaemia-SBT).

\section{Basic Laboratory Investigations}

Hematological parameters $(\mathrm{Hb} \%, \mathrm{MCV}$, $\mathrm{MCH}$ and $\mathrm{MCHC}$ ) were measured on an automated blood cell counter (Cellenium 19, China). Sickle hemoglobin was identified by sickling test with $2 \%$ sodium metabisulphite and confirmed by electrophoresis (Figure-1) on cellulose acetate membrane with TEB buffer (Tris-EDTA-Borate) at $\mathrm{pH} \quad 8.6$ (Chanarin, 1989). $\mathrm{HbA}_{2}$ was quantified by elution from Cellulose acetate membrane (Dacie et al., 1991). 


\section{Molecular Screening by PCR}

DNA was extracted by the using genomic DNA purification kit (K0512, Thermo Fisher Scientific Inc.) and Polymerase chain reaction was used to detect $-\alpha^{3.7}$ and $-\alpha^{4.2}$ deletions (Figur-2 \& Figure-3) as described earlier (Baysal et al., 1984). Beta thalassaemia mutations were characterized by ARMS PCR (Mohanty et al., 2008).

\section{Results and Discussion}

Molecular analysis of 300 homozygous sickle cell anemia (SCA) and 60 sickle beta thalassemia (SBT) individuals were carried out for $-\alpha^{3.7}$ and $-\alpha^{4.2}$ deletions. Table-1 shows the deletion profile of SCA and SBT individuals included in the study. The overall prevalence of $\alpha$-thalassaemia was $40.2 \%$. Group wise prevalence was $41.3 \%$ for SCA and $35.0 \%$ for SBT subjects and this difference was statistically not significant.

Majority of homozygous sickle cell anemia patients (30.7\%) were heterozygous for $\alpha$ thalassemia deletion $(-\alpha / \alpha \alpha)$ and $9.3 \%$ carried homozygous $(-\alpha /-\alpha)$ deletions. The $\alpha^{3.7}$ deletion was higher $(31.6 \%)$ than $-\alpha^{4.2}$ deletion $(11.0 \%)$ while $1.3 \%$ showed both deletions $\left(-\alpha^{3.7} /-\alpha^{4.2}\right)$. As in the case of $\alpha$ thalassemia, majority of sickle beta thalassemia (SBT) individuals also showed $\alpha / \alpha \alpha(30.0 \%)$ deletion and only $5.0 \%$ were homozygous for $-\alpha /-\alpha$ deletion. SBT subjects showed predominantly $-\alpha^{3.7}$ deletion $(25.0 \%)$ followed by $-\alpha^{4.2}$ deletion $(10.0 \%)$. Notably, no double heterozygous condition was encountered among the present SBT study subjects also.

Effort was also made to identify whether the co-existing of $\alpha$-thalassaemia with sickle cell disease (SCA \& SBT) showed any relationship with regard to caste as sickle cell hemoglobin was found to be associated with communities involved in endogamous marriage practices. Table- 2 depicts caste wise analysis of $\alpha$-thalassaemia mutations in sickle cell disease individuals. Among the SCA, higher number of Scheduled tribe individuals (Gond and Pradhan) carried $\alpha$ thalassaemia mutations $(61.9 \%)$ followed by $50.0 \%$ in other backward class (Patel, Yadav and Barman) and $34.5 \%$ in Scheduled castes (Chadar Deharia, Jharia, Katiya, Mahar, Mehra). About 18\% Muslims and Rajpoots also showed $\alpha$-thalassaemia mutations (Table-2). In case of SBT individuals, all Scheduled tribe subjects carried $\alpha$ thalassaemia followed by $34.8 \%$ of other backward class, $18.2 \%$ others and Scheduled caste $(11.8 \%)$ respectively.

Mutational analysis on sixty sickle beta thalassaemia (SBT) study individuals were carried out to identify the presence of common $\beta$-thalassaemia mutations such as IVS1-5 $(\mathrm{G} \rightarrow \mathrm{C})$, Codon $15(\mathrm{G} \rightarrow \mathrm{A})$, Codon 8/9 (+G), Codon 41/42 (-TCTT), IVS1$1(\mathrm{G} \rightarrow \mathrm{A})$ and 619-bp deletions. The majority $(80.0 \%)$ of the studied SBT population were found to carry IVS1-5 $(\mathrm{G} \rightarrow \mathrm{C})$ mutation (Figure-4) and other mutations namely Codon15 $(\mathrm{G} \rightarrow \mathrm{A})$, Codon $8 / 9(+\mathrm{G})$ and Codon 41/42 (-TCTT) were in equal frequency $(6.7 \%)$. The IVS1-1(G $\rightarrow \mathrm{A})$ and 619-bp deletion were not detected in the studied subjects. The IVS1-5 $(\mathrm{G} \rightarrow \mathrm{C})$ mutation was found in all Scheduled tribe individuals followed by OBC (87.0\%), others $(72.7 \%)$ and SC (64.7\%). The Codon15 $(\mathrm{G} \rightarrow \mathrm{A})$ mutation was found only in SCs $(23.5 \%)$ whereas Codon 8/9 $(+\mathrm{G})$ was found among Muslims \& Rajpoots (27.3\%) and other backward classes (4.3\%) only. Codon 41/42 (-TCTT) was encountered only among Scheduled caste $(11.8 \%)$ and other backward classes (8.7\%).

The effect of $\alpha$-thalassaemia on red cell 
indices of SCA and SBT were evaluated. The mean hemoglobin levels of SCA with or without $\alpha$-thalassaemia were in the range of moderate anemia and no significant differences were observed either in the hemoglobin levels or HCT (Table-3). On the other hand, mean $\mathrm{MCV}(\mathrm{P}=0.0001)$ and $\mathrm{MCH} \quad(\mathrm{P}=0.0001)$ of SCA with $\alpha$ thalassaemia were significantly lower than non $\alpha$-thalassaemia individuals. Interestingly, significant increase in mean total red cell count $(\mathrm{P}=0.0001)$ was observed in $\alpha$-thalassaemia subjects when compared with non-thalassaemia group. No significant difference in mean $\mathrm{HbF}$ levels was observed between any of the groups. On the other hand, the mean MCV $(\mathrm{P}=0.0216)$ and $\mathrm{MCH}$ $(\mathrm{P}=0.0213)$ of individuals with homozygous $(-\alpha /-\alpha)$ were significantly lower than heterozygous $(-\alpha / \alpha \alpha)$ individuals. In contrast, presence or absence $\alpha$-thalassaemia mutation did not affect hematological indices of SBT individuals.

Alpha thalassaemia is a known major modifier in sickle cell disease presentation (Thein 2008). Identification of the presence of $\alpha$-deletions in sickle cell disease patients of any given population is a pre-requisite to recognizing its effect on sickle cell disease presentation. Three hundred and sixty sickle cell subjects were evaluated for $\alpha$ thalassaemia deletions. About $40.2 \%$ of cases were found to carry $\alpha$-thalassemia deletions predominantly among tribal individuals of both SCA $(61.9 \%)$ and SBT $(100 \%)$ cases. Majority of the individuals were heterozygous $(-\alpha / \alpha \alpha)$ for $-\alpha^{3.7}$ deletion or $-\alpha^{4.2}$ deletion. The $-\alpha^{3.7}$ deletion was predominant over $-\alpha^{4.2}$ deletion. In Africa about one third of sickle cell anemia patients have been shown to carry coexisting $\alpha$ thalassemia $\left(-\alpha^{3.7}\right.$ deletion) in heterozygous and homozygous states (Steinberg, 2009). Further, sickle cell anaemia patients in Brazil, California and Guadeloupe were been found to carry $\alpha$-thalassaemia (Figueiredo et al., 1996; Kéclard et al., 1996; Schroeder et al., 1989). In India, about $30 \%$ of sickle cell anemia patients in a hospital based study, all the tribals in Western India and $32 \%$ of non-tribal sickle homozygous individuals were found to carry a-thalassaemia (Sanjay et al., 2011; Mukherjee et al., 1997a).

Table.1 Percent prevalence of $\alpha$-thalassaemia in sickle cell disease patients of Madhya Pradesh (India)

\begin{tabular}{|l|c|c|c|c|c|c|c|}
\hline & $\begin{array}{c}\text { No. of } \\
\text { Patients }\end{array}$ & $\alpha \alpha / \alpha \alpha$ & $-\alpha^{3.7} /-\alpha^{3.7}$ & $-\alpha^{3.7} / \alpha \alpha$ & $\alpha \alpha /-\alpha^{4.2}$ & $-\alpha^{3.7} /-\alpha^{\mathbf{4 . 2}}$ & $\begin{array}{c}\text { Total } \\
\alpha-\text {-thal. }\end{array}$ \\
\hline $\begin{array}{l}\text { Homozygous sickle } \\
\text { cell disease (SCA) }\end{array}$ & $\mathbf{3 0 0}$ & 58.7 & 9.3 & 21.0 & 9.7 & 1.3 & 41.3 \\
\hline $\begin{array}{l}\text { Sickle } \beta- \\
\text { thalassaemia (SBT) }\end{array}$ & $\mathbf{6 0}$ & 65.0 & 5.0 & 20.0 & 10.0 & 0 & 35.0 \\
\hline Total & $\mathbf{3 6 0}$ & $\mathbf{5 9 . 8}$ & $\mathbf{8 . 6}$ & $\mathbf{2 0 . 8}$ & $\mathbf{9 . 7}$ & $\mathbf{1 . 1}$ & $\mathbf{4 0 . 2}$ \\
\hline
\end{tabular}


Table. 2 Percent prevalence of $\alpha$-thalassaemia in sickle cell disease patients and their caste distribution

\begin{tabular}{|l|c|c|c|}
\hline \multirow{2}{*}{ Caste } & & $\begin{array}{c}\text { No. of } \\
\text { Patients }\end{array}$ & $\begin{array}{c}\boldsymbol{\alpha} \text {-thal. } \\
(\mathbf{\%})\end{array}$ \\
\hline \multirow{2}{*}{ Scheduled caste (194) } & SCA & 177 & 34.5 \\
\cline { 2 - 4 } & SBT & 17 & 11.8 \\
\hline \multirow{2}{*}{ Scheduled tribe (51) } & SCA & 42 & 61.9 \\
\cline { 2 - 4 } & SBT & 9 & 100.0 \\
\hline \multirow{2}{*}{ Other backward class (93) } & SCA & 70 & 50.0 \\
\cline { 2 - 4 } & SBT & 23 & 34.8 \\
\hline \multirow{2}{*}{ Others (22) } & SCA & 11 & 18.2 \\
\cline { 2 - 4 } & SBT & 11 & 18.2 \\
\hline \multirow{2}{*}{ Total (360) } & SCA & $\mathbf{3 0 0}$ & $\mathbf{4 1 . 3}$ \\
\cline { 2 - 4 } & SBT & $\mathbf{6 0}$ & $\mathbf{3 5 . 0}$ \\
\hline$*$ Values in parenthesis are total number of patients \\
\hline
\end{tabular}

Table.3 Mean hematological indices of Sickle cell disease and effect of $\alpha$-thalassemia

\begin{tabular}{|c|c|c|c|c|c|c|c|c|}
\hline Genotype & $\mathbf{N}$ & $\begin{array}{c}\text { Hb } \\
(\mathrm{g} / \mathrm{dl}) \\
(\text { Mean } \pm \text { SD })\end{array}$ & $\begin{array}{c}\text { HCT } \\
(\%) \\
(M e a n \pm S D) \\
\end{array}$ & $\begin{array}{c}\text { TRBC } \\
\left(X 1^{6}\right) \\
(M e a n \pm S D)\end{array}$ & $\begin{array}{c}\text { MCV } \\
(\mathbf{f l}) \\
(\text { Mean } \pm \text { SD }) \\
\end{array}$ & $\begin{array}{c}\text { MCH } \\
(\mathbf{p g}) \\
(\mathrm{Mean} \pm \mathrm{SD})\end{array}$ & $\begin{array}{c}\text { MCHC } \\
(\text { g/dl }) \\
(\text { Mean } \pm \text { SD })\end{array}$ & $\begin{array}{c}\text { HbF } \\
(\%) \\
(\text { Mean } \pm \text { SD })\end{array}$ \\
\hline $\begin{array}{l}\alpha \alpha / \alpha \alpha \\
(\mathrm{SCA})\end{array}$ & 176 & $7.8 \pm 1.8$ & $24.6 \pm 5.4$ & $2.9 \pm 0.7$ & $87.3 \pm 8.9$ & $27.9 \pm 4.0$ & $31.9 \pm 2.6$ & $15.5 \pm 6.3$ \\
\hline \multirow[t]{2}{*}{$\begin{array}{l}\alpha \text {-thal } \\
\text { (SCA) }\end{array}$} & 124 & $7.9 \pm 1.6$ & $25.1 \pm 4.8$ & $3.3 \pm 0.8$ & $78.2 \pm 9.2$ & $24.6 \pm 3.6$ & $31.8 \pm 5.1$ & $14.4 \pm 5.6$ \\
\hline & & & & $P=0.0001$ & $P=0.0001$ & $P=0.0001$ & & \\
\hline $\begin{array}{l}-\alpha / \alpha \alpha \\
(\mathrm{SCA})\end{array}$ & 92 & $7.9 \pm 1.5$ & $25.1 \pm 4.6$ & $3.2 \pm 0.7$ & $79.3 \pm 9.1$ & $25.1 \pm 3.6$ & $31.5 \pm 2.5$ & $14.9 \pm 5.8$ \\
\hline \multirow[t]{2}{*}{$\begin{array}{l}-\alpha /-\alpha \\
(\mathrm{SCA})\end{array}$} & 32 & $7.9 \pm 1.8$ & $25.3 \pm 5.3$ & $3.4 \pm 0.9$ & $75.0 \pm 8.7$ & $23.4 \pm 3.4$ & $31.1 \pm 1.8$ & $13.2 \pm 4.9$ \\
\hline & & & & & $P=0.0216$ & $\mathrm{P}=\mathbf{0 . 0 2 1 3}$ & & \\
\hline $\begin{array}{l}\alpha \alpha / \alpha \alpha \\
(\mathrm{SBT})\end{array}$ & 39 & $7.3 \pm 1.6$ & $24.4 \pm 5.1$ & $3.7 \pm 0.9$ & $68.1 \pm 8.1$ & $20.5 \pm 3.1$ & $30.1 \pm 1.7$ & $17.2 \pm 6.2$ \\
\hline $\begin{array}{l}\alpha \text {-thal } \\
\text { (SBT) }\end{array}$ & 21 & $7.4 \pm 1.8$ & $24.4 \pm 5.5$ & $3.5 \pm 0.9$ & $71.5 \pm 7.9$ & $21.7 \pm 3.0$ & $30.3 \pm 1.7$ & $14.1 \pm 5.6$ \\
\hline
\end{tabular}


Fig.1 Hemoglobin electrophoresis on cellulose acetate medium

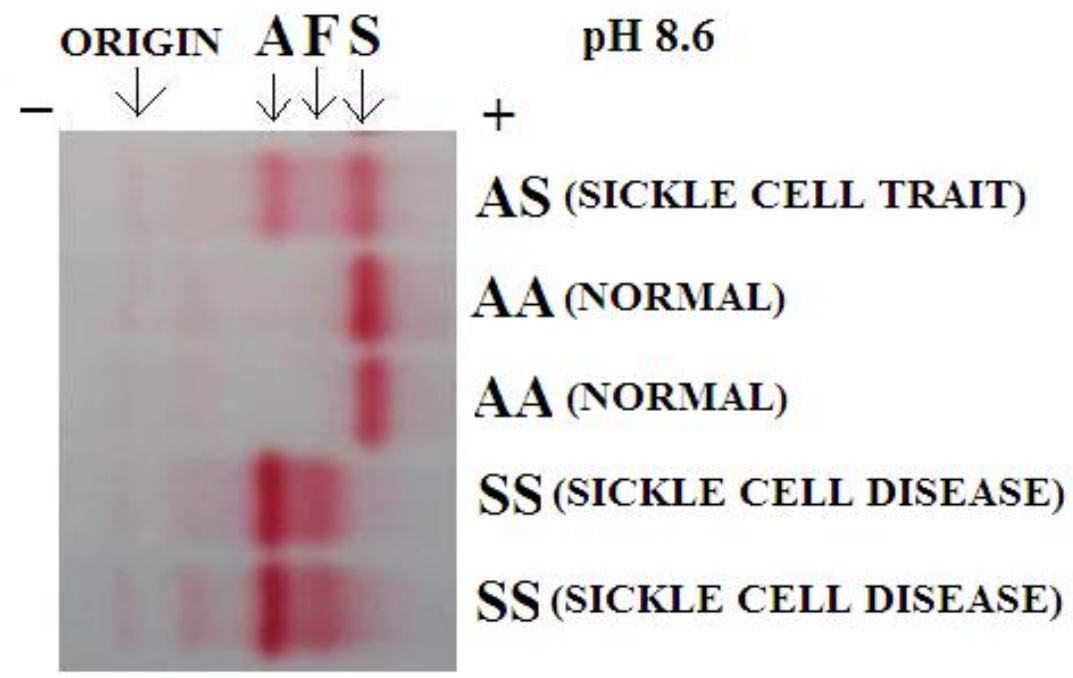

Fig.2 Agarose gel electrophoresis of PCR product to detect -3.7 deletion

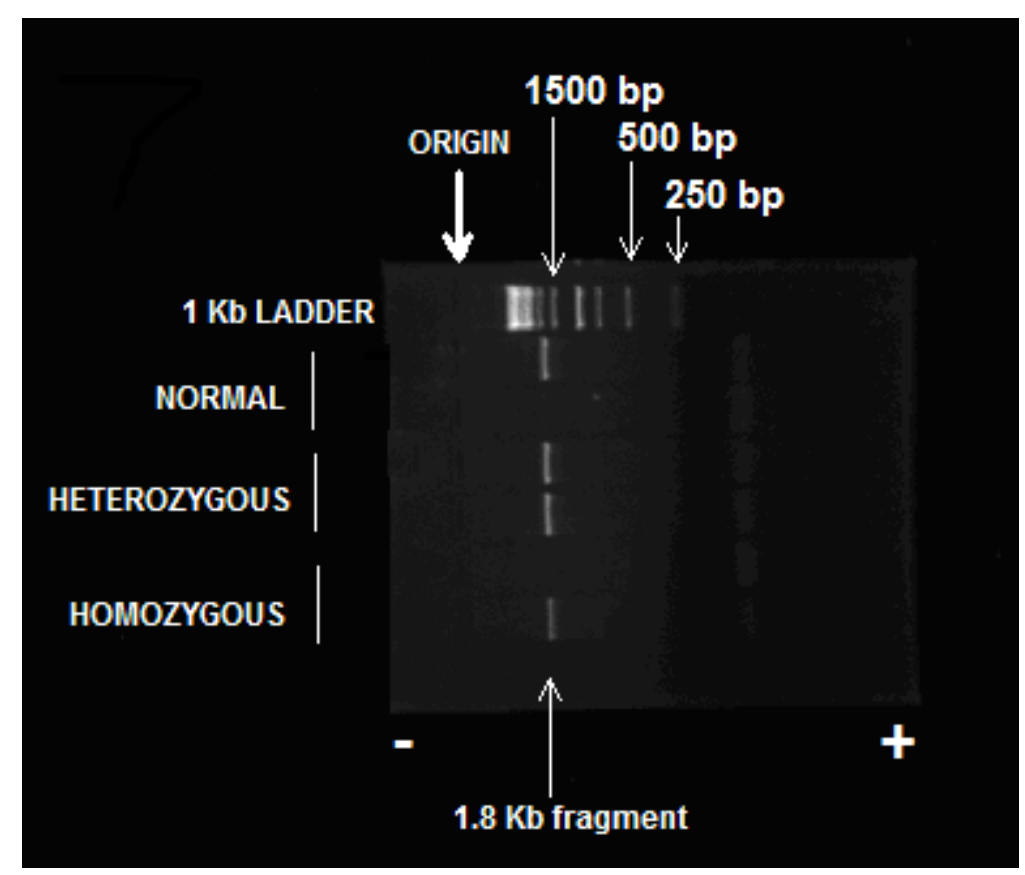


Fig.3 Agarose gel electrophoresis of PCR product to detect -4.2 deletion

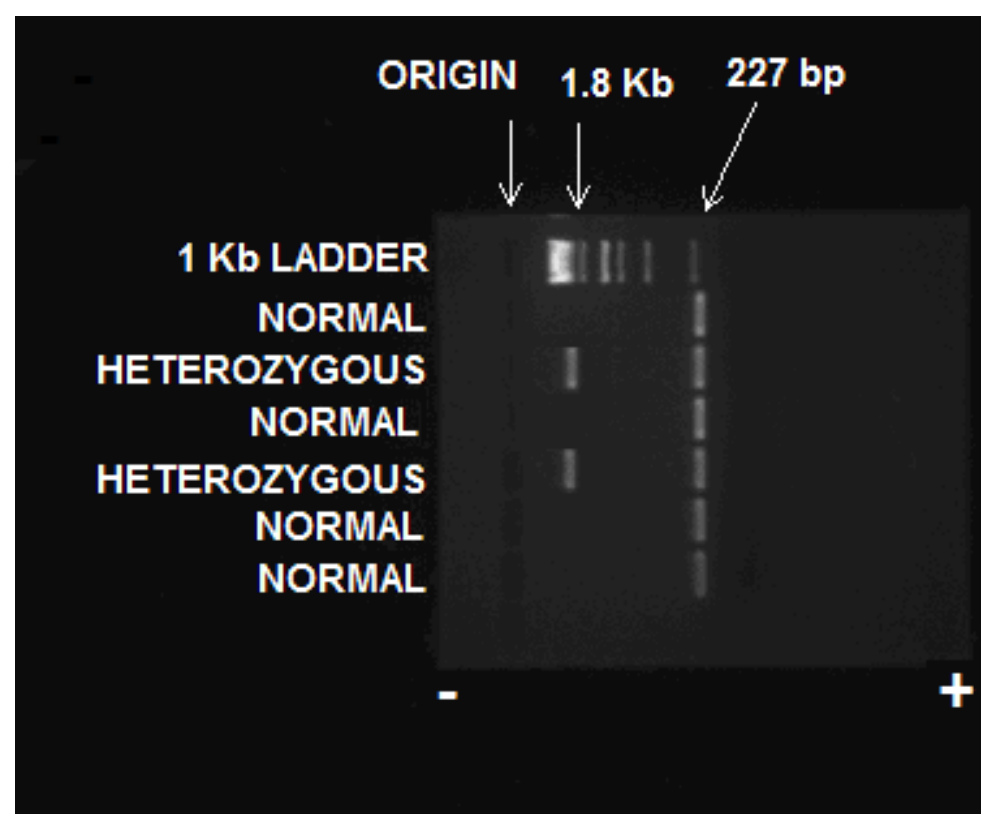

Fig.4 Percent prevalence of beta thalassaemia mutations in sickle cell disease patients

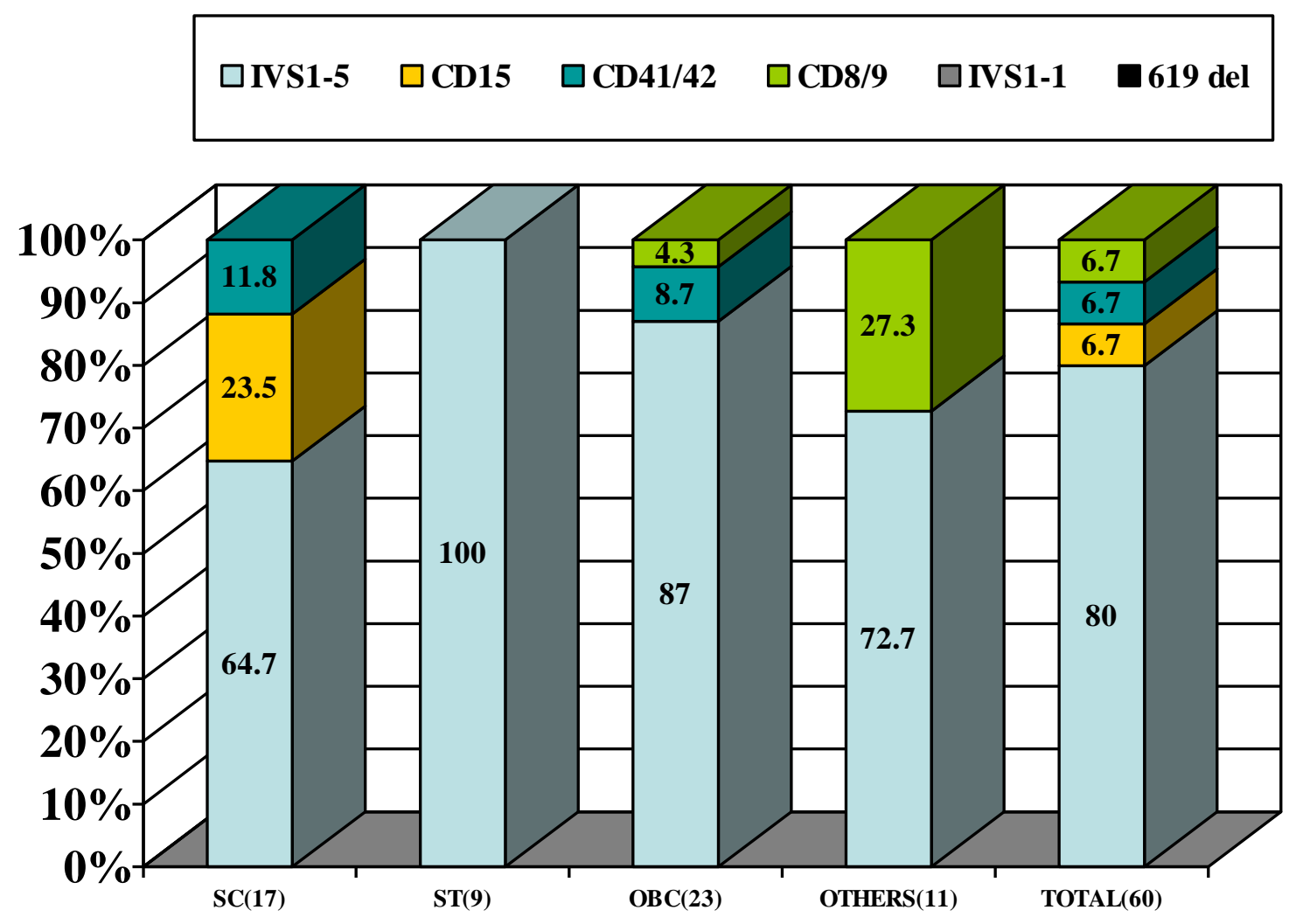


Recently, Yadav et al., 2016 reported variation in the clinical phenotype of Sickle cell disease patients with different genotypes. Moreover, it is reported that SCD individuals with $\alpha^{+}$-thalassaemia show higher hemoglobin level but lower mean corpuscular volume (MCV), mean corpuscular hemoglobin $(\mathrm{MCH})$ and mean corpuscular hemoglobin concentration (MCHC) with resultant lower clinical severity (Higgs et al., 1982; Embury et al., 1982). In the present investigations, SCA patients with $\alpha^{+}$-thalassaemia showed significantly higher mean red cell count (TRBC), lower MCV and lower $\mathrm{MCH}$ but no difference in mean hemoglobin levels.

Earlier reports on $\alpha^{+}$-thalassaemia in SCD patients in India have also shown significantly higher levels of hemoglobin, hematocrit (HCT), TRBC counts, $\mathrm{HbA}_{2}$ levels and lower MCV, MCH resulting in milder clinical presentation (Mukherjee et al., 1997b; Mukherjee et al., 1998). Presence of alpha thalassemia in sickle cell disease individuals results in reduction in intracellular concentration of $\mathrm{HbS}$ and consequent $\mathrm{HbS}$ polymerization and associated crisis (Steinberg et al., 2012). In contrast, the $\mathrm{MCV}, \mathrm{MCH}$ and $\mathrm{MCHC}$ indices of alpha thalassaemic SBT individuals were marginally higher but statistically insignificant.

The IVS1-5(G $\rightarrow$ C $)$ mutation is the most common mutation found in India and the mutations included in the study are often responsible for $\beta^{0}$-thalassaemia (Sinha et al., 2009; Thein 2013). The prevalence of common beta thalassaemia mutations in different categories of population ethnic or otherwise will facilitate molecular pre and post natal testing to aid in clinical diagnosis in both symptomatic and non symptomatic individuals. The small sample size in the present studies may be considered as a bias or drawback but it illustrates wide prevalence of the genetic diseases in the communities of the region emphasizing the need for broader studies. Finally the present study overwhelmingly demonstrates that more than one third sickle cell disease individuals in Madhya Pradesh carry the $\alpha$ deletions. These coexisting mutations may not only modulate the hematological severity but also the clinical expression and serve as a predictor of disease severity.

\section{Acknowledgements}

The authors are grateful to Dr. Neeru Singh, Director of NIRTH (ICMR), Jabalpur for the kind permission and facilities given for this study. The authors are also grateful to staff of Genetics department Dr. Rajiv Yadav, Mr. Subhash Godbole, Mr. C.P.Vishwakarma, Mr. Ashok Gupta, Mr. R.L.Neelkar, Mr. Anil Gwal, Mr.P. Patel for their help and support in this study. Authors also acknowledge that this study has been done in collaboration with NIRTH, Jabalpur. Study subjects, laboratory facilities as well as chemicals needed for the study were provided by NIRTH.

\section{References}

Baysal, E., Huisman, T.H.J. 1994. Detection of common deletional alpha thalassaemia-2 determinants by PCR: Am. J. Haematol., 46(3): 208-213.

Bunn, H.F. 1997. Pathogenesis and treatment of sickle cell disease. N. Engl. J. Med., 337(11): 762-769.

Chanarin, I. 1989. Laboratory Haematology: An account of Laboratory Techniques. $1^{\text {st }}$ edition Pub. by Churchill Livingstone, London.

Dacie, J.V. and Lewis, S.M. 1991. Practical Haematology: Seventh Edition. Churchill Livingstone, London.

Embury, S.H., Miller, J.A., Dozy, A.M., Kan, Y.W., Chan, V., Todd D. 1980. Two different molecular organizations 
account for the single $\alpha$-globin gene of the $\alpha$-thalassemia-2 genotype. J. Clin. Invest., 66(6): 1319-1325.

Embury, S.H., Dozy, A.M., Miller, J., Davis, J.R. Jr, Kleman, K.M., Preisler, H., Vichinsky, E., Lande, W.N., Lubin, B.H., Kan, Y.W., Mentzer, W.C. 1982. Concurrent sickle-cell anemia and $\alpha$ thalassemia. Effect on severity of anemia: N. Engl. J. Med., 306(5): 270274.

Figueiredo, M.S., Kerbauy, J., Gonçalves, M.S., Arruda, V.R., Saad, S.T., Sonati, M.F., Stoming, T., Costa, F.F. 1996. Effect of $\alpha$-thalassemia and $\beta$-globin gene cluster haplotypes on the hematological and clinical features of sickle-cell anemia in Brazil. Am. J. Hematol., 53(2): 72-76.

Flint, J., Hill, A.V.S., Bowden, D.K., Oppenheimer, S.J., Sill, P.R., Serjeantson, S.W., Bana-Koiri, J., Bhatia, K., Alpers, M.P., Boyce, A.J., Weatherall, D.J., Clegg, J.B. 1986. High frequencies of $\alpha$ thalassaemia are the result of natural selection by malaria. Nature, 321(6072): 744-750.

Higgs, D.R., Aldridge, B.E., Lamb, J., Clegg, J.B., Weatherall, D.J., Hayes, R.J., Grandison, Y., Lowrie, Y., Mason, K.P., Serjeant, B.E., Serjeant, G.R. 1982. The interaction of $\alpha$-thalassemia and homozygous sickle cell disease. $N$. Engl. Med., 306(24): 1441-1446.

Higgs, D.R., Engel, J.D., Stamatoyannopoulos, G. 2012. Thalassaemia. Lancet, 379(9813): 373-383.

Higgs, D.R. 2013. The molecular basis of $\alpha-$ thalassemia. Cold Spring Harb Perspect Med., 3(1): a011718.

Ingram, V.M. 1956. A specific chemical difference between the globins of normal human and sickle-cell anaemia haemoglobin. Nature, 178(4537): 792794.

Kéclard, L., Ollendorf, V., Berchel, C.,
Loret, H., Mérault, G. 1996. $\beta^{\text {S- }}$ haplotypes, $\alpha$-globin gene status and hematological data of sickle cell disease patients in Guadeloupe. Hemoglobin, 20(1): 63-74.

Mohanty, D., Colah, R. 2008. Laboratory Manual for screening,diagnosis and molecular analysis of haemoglobinopathies and red cell enzymopathies. Bhalani Publishing house, Mumbai, Pg 98-101.

Mukherjee, M.B., Lu, C.Y., Ducrocq, R., Raman, R., Gangakhedkar, Colah, R.B., Kadam, M.D., Mohanty, D., Nagel, R.L., Krishnamoorthy, R. 1997a. Effect of $\alpha$-Thalassemia on Sickle-Cell Anemia Linked to the Arab-Indian Haplotype in India. American J. Hematol., 55(2): 104-109.

Mukherjee, M.B., Colah, R.B., Ghosh, K., Mohanty, D. and Krishnamoorthy, R. 1997b. Milder Clinical Course of Sickle Cell Disease in Patients With alpha Thalassemia in the Indian Subcontinent. Blood, 89(2): 732.

Mukherjee, M.B., Surve, R., Tamankar, A., Gangakhedkar, R.R., Ghosh, K., Lu, C.Y., Krishnamoorthy, R., Colah, R., Mohanty, D. 1998. The influence of alpha thalassaemia on the haematological and clinical expression of sickle cell disease in western India. Indian J. Med. Res., 107: 178-181.

Pauling, L., Itano, H., Singer, S.J. and Wells, I.C. 1949. Sickle cell anemia: a molecular disease. Sci., 110(2865): 543-548.

Sanjay, P., Sweta, P., Rahasya, M.M., Monica, S., Renu, S. 2011. Genotypic influence of $\alpha$-deletions on the phenotype of Indian sickle cell anemia patients. Korean J. Hematol., 46(3): 192-195.

Schroeder, W.A., Powars, D.R., Kay, L.M. et al., 1989. $\beta$-cluster haplotypes, $\alpha$-gene status and hematological data from SS, 
SC and S- $\beta$-thalassemia patients in southern California. Hemoglobin, 13(4): 325-353.

Singh, M.P.S.S., Gupta, R.B., Yadav, R., Sharma, R.K., Rajasubramaniam, S. 2016. Prevalence of $\alpha^{+}$-Thalassemia in the Scheduled Tribe and Scheduled Caste Populations of Damoh District in Madhya Pradesh, Central India. Hemoglobin., DOI: 10.3109/03630269.2016.1170031.

Published online on 18 May 2016.

Sinha, S., Black, M.L., Agarwal, S., Colah, R., Das, R,. Ryan, K., Bellgard, M., Bittles, A.H. 2009. Profiling beta thalassaemia mutations in India at state and regional levels: implications for genetic education, screening and counselling programmes. Hugo J., 3(14): 51-62.

Steinberg, M.H. 2009. Genetic Etiologies for Phenotypic Diversity in Sickle Cell Anemia. Special Issue: Hemoglobinopathies. The Scientific World J., 9: 46-67. doi: 10.1100/tsw.

Steinberg, M.H., Sebastiani, P. 2012. Genetic modifiers of sickle cell disease. Am. J. Hematol., 87(8): 795-803. doi: 10.1002/ajh.23232.

Thein, S.L. 2008. Genetic modifiers of the beta haemoglobinopathies. British $J$.
Haematol., 141(3): 357-366. doi: 10.1111/j.1365-141.2008.07084.x

Thein, S.L. 2013. The molecular basis of $\beta$ thalassaemia. Cold Spring Harb Perspect Med., 3(5):a011700. doi: 10.1101/cshperspect.a011700

Weatherall, D.J. 2001. Phenotype-genotype relationships in monogenic disease. Lessons from the thalassaemias. Nature Reviews Genetics, 2(4): 245-255.

Weatherall, D.J., Clegg, J.B. 2001a. The Thalassaemia Syndromes. Blackwell Science, Oxford.

Weatherall, D.J., Clegg, J.B. 2001b. Inherited haemoglobin disorders: an increasing global health problem. Bull. World Health Organisation, 79(8): 704-712. Yadav, R., Lazarus, M., Ghnaghoria, P., Singh, M.P.S.S., Gupta, R.B., Kumar, S., Sharma, R.K., Rajasubramaniam, S. 2016. Sickle Cell Disease in Madhya Pradesh, Central India: a comparison of Clinical profile of Sickle Cell Homozygote Vs Sickle-beta thalassemia individuals. Hematol., DOI: $10.1080 /$ 10245332.2016 .1148893$.

\section{How to cite this article:}

Singh, M.P.S.S., G. Sudhakar and Rajasubramaniam, S.. 2016. Prevalence of Thalassaemia Mutations in Sickle Cell Disease Population of Madhya Pradesh, Central India. Int.J.Curr.Microbiol.App.Sci. 5(7): 768-777. doi: http://dx.doi.org/10.20546/ijcmas.2016.507.088 